\title{
HLA-DRB4 wt Allele
}

National Cancer Institute

\section{Source}

National Cancer Institute. HLA-DRB4 wt Allele. NCI Thesaurus. Code C71262.

Human HLA-DRB4 wild-type allele is located in the vicinity of 6p21.3 and is approximately $15 \mathrm{~kb}$ in leng th. This allele, which encodes HLA class II histocompatibility antigen, DRB4 beta chain protein, plays a role in the regulation of antigen presentation. The gene is polymorphic and typing is often performed to determine histocompatibility for hematopoietic stem cell transplantation. 